\title{
Characterization of Functional GABAergic Synapses Formed between Rat Hypothalamic Neurons and Pituitary Intermediate Lobe Cells in Coculture: $\mathrm{Ca}^{2+}$ Dependence of Spontaneous IPSCs
}

\author{
Pierrick Poisbeau, Frédérique René, Christophe Egles, Jean-Marc Félix, Paul Feltz, and Rémy Schlichter \\ Laboratoire de Neurophysiologie et de Neurobiologie des Systèmes Endocrines, 67084 Strasbourg Cedex, France
}

\begin{abstract}
Rat hypothalamic neurons and endocrine cells from the intermediate lobe of the pituitary were grown in dissociated coculture. Neurons positively stained with an antibody against glutamate decarboxylase established apparent contacts with the $\alpha$-melanocyte-stimulating hormone-positive endocrine cells. These sites of contact were intensely labeled with an antibody against the synaptic protein synapsin I and displayed ultrastructural features characteristic of synapses. Using patchclamp recordings, we have demonstrated that these contacts correspond to functional GABAergic synapses. The synaptic currents were blocked reversibly by bicuculline $(5 \mu \mathrm{M})$ and SR95531 $(5 \mu \mathrm{M})$, two competitive antagonists of the GABA receptor. At a holding potential of $-60 \mathrm{mV}$, spontaneously occurring IPSCs (s-IPSCs) had small amplitudes (10-100 pA), whereas electrically evoked IPSCs (ee-IPSCs) had amplitudes up to $1 \mathrm{nA}$. The rise times of both types of IPSCs were fast $(\leq 1$
\end{abstract}

msec), and their decaying phases were fitted in most cases with a single exponential function (time constant, $50 \mathrm{msec}$ ). The amplitude distribution of s-IPSCs did not reveal clear, equally spaced peaks and was little affected by tetrodotoxin, suggesting that most s-IPSCs were miniature IPSCs. Reduction of extracellular calcium concentration to $0.3 \mathrm{~mm}$ induced a marked decrease in S-IPSC frequency and revealed a single amplitude peak at $10 \mathrm{pA}$, suggesting that a single quantum of GABA activates 8-10 GABA $A_{A}$ channels. Thus, our preparation might be an interesting model to study different aspects of synapse formation between a central neuron and its target as well as the fundamental mechanisms of synaptic transmission at central synapses.

Key words: inhibitory postsynaptic currents; synaptic transmission; synaptogenesis; hypothalamo-hypophyseal coculture; neuroendocrine interaction; GABA
The intermediate lobe (IL) of the pituitary constitutes a homogeneous population of excitable endocrine cells (melanotrophs), which mainly secrete $\alpha$-melanocyte-stimulating hormone ( $\alpha$ MSH) in a calcium-dependent manner (Bower and Hadley, 1972; Tomiko et al., 1981). A unique feature of these endocrine cells is that their electrical and secretory activities are controlled by the CNS under the form of direct synaptic contacts established between hypothalamic neurons and melanotrophs. Morphological studies have revealed that these nerve fibers contain dopamine (Björklund et al., 1973) and GABA (Oertel et al., 1982; Vincent et al., 1982), two inhibitory neurotransmitters that are colocalized in the nerve terminals (Vuillez et al., 1987). From a functional point of view, both dopamine (Douglas and Taraskevitch, 1978, 1982; Tilders et al., 1985; Valentijn et al., 1991) and GABA (Taraskevitch and Douglas, 1982, 1985; Tomiko et al., 1983; Demeneix et al., 1986) inhibit the electrical and secretory activities of melanotrophs. Intracellular recordings performed in IL cells of freshly excised neurointermediate lobes (NILs) of the rat pituitary have demonstrated that electrical stimulation of the pituitary stalk induces two types of postsynaptic responses in

\footnotetext{
Received March 29, 1996; revised May 7, 1996; accepted May 14, 1996.

This research was supported by Direction des Recherches et Techniques (93086), Université Louis Pasteur, Centre National de la Recherche Scientifique, and the European Community (contract ERBCHRXCT 940569). We thank Dr. M.-E. Stoeckel for help with the electron microscopy, Dr. A. Marty for discussion, and J.-M. Gachon for performing the photographic work.

Correspondence should be addressed to R. Schlichter, Université Louis Pasteur, Laboratoire de Physiologie Générale, Unité de Recherche Associée 1446-Centre National de la Recherche Scientifique, 21 Rue Descartes, 67084 Strasbourg Cedex, France.

Copyright (C) 1996 Society for Neuroscience $0270-6474 / 96 / 164835-11 \$ 05.00 / 0$
}

melanotrophs (MacVicar and Pittman, 1986). The first consists of a fast IPSP mediated by an increase in chloride conductance via the activation of $\mathrm{GABA}_{\mathrm{A}}$ receptors (MacVicar and Pittman, 1986). The second type of response is a slow IPSP mediated by a $\mathrm{K}^{+}$conductance controlled by the activation of dopamine $\mathrm{D}_{2}$ receptors (Williams et al., 1989). In addition, synaptically released dopamine inhibits voltage-dependent calcium currents (Williams et al., 1990).

Recently, thin slices of rat NILs (Schneggenburger and Konnerth, 1992) or freshly excised bullfrog NILs (Borst et al., 1994) have been used to study in more detail the properties of the GABAergic synaptic transmission in the hypothalamohypophyseal system with the patch-clamp technique. A major advantage of this preparation is the electrical compactness of the postsynaptic melanotrophs because of their small size (10-12 $\mu \mathrm{m})$, their high-input resistance, and the absence of cellular processes, thus allowing the recording of synaptic currents with a high signal-to-noise ratio under good space-clamp conditions. Moreover, because the synaptic events arise close to the site of recording, they are not distorted significantly or attenuated by the cable properties of these cells, a problem often encountered at neuroneuronal synapses (Redman, 1990; Bekkers, 1994; Edwards, 1995). However, one major disadvantage of excised NILs or slice preparation of NILs is the fact that the nerve fibers innervating the intermediate pituitary necessarily have been cut, because the cell bodies of the neurons are located in the hypothalamus. We have decided to take an alternative approach by establishing a coculture of hypothalamic neurons and melanotrophs suitable for both morphological and electrophysiological studies. This system has allowed us to characterize the formation of functional 
GABAergic synapses and to study the synaptic transmission between identified pairs of cells with ideal pharmacological access to the synaptic cleft under conditions in which the integrity of the presynaptic neuron has been maintained.

\section{MATERIALS AND METHODS}

\section{Tissue culture}

Preparation of hypothalamic neurons. Pregnant Wistar rats at day 15 of gestation were anesthetized with pentobarbital, and the embryos were removed. The diencephalon was dissected out under a stereomicroscope, and the area corresponding to the basal hypothalamus was isolated. The fragments of tissue were incubated for $7 \mathrm{~min}$ at $37^{\circ} \mathrm{C}$ under constant agitation in a divalent-free PBS containing trypsin and EDTA (0.05$0.02 \%$; Life Technologies). The enzymatic dissociation was stopped by adding $20 \%$ fetal calf serum (FCS). After centrifugation $(3 \mathrm{~min}$ at $180 \times$ $g$ ), the supernatant was removed and replaced with $2 \mathrm{ml}$ of DMEM (Life Technologies) containing 20\% FCS (Life Technologies); mechanical dissociation was performed with Pasteur pipettes of decreasing tip diameter. After centrifugation $(7 \mathrm{~min}$ at $180 \times g)$, the pellet containing the dissociated cells was resuspended in serum-free medium according to the method of Bottenstein and Sato (1979). Hypothalamic neurons were seeded at a density of 400 cells $/ \mathrm{mm}^{2}$ in $35 \mathrm{~mm}$ petri dishes (Costar, Cambridge, MA) for electrophysiological studies or at a density of 800 cells $/ \mathrm{mm}^{2}$ on 8 -mm-diameter coverslips in four-well multidishes $(15 \mathrm{~mm}$ diameter) for immunocytochemical and electron microscopic studies. Before the cells were seeded, Petri dishes and coverslips were coated with poly-L-lysine (10 $\mu \mathrm{g} / \mathrm{ml}$; Sigma, St. Louis, MO) and preincubated for $1 \mathrm{hr}$ with a PBS containing $10 \%$ FCS.

Preparation of intermediate lobe cells. Neonatal (1-7 d) Wistar rats were killed by decapitation under diethyl ether anesthesia. Pituitaries were removed and extensively washed in PBS; the NILs were separated from anterior lobes by using thin forceps. Melanotrophs were obtained after enzymatic and mechanical dissociation of the NILs, following the procedure described above for hypothalamic neurons, and seeded on top of the hypothalamic neurons at densities of 80 and 200 cells $/ \mathrm{mm}^{2}$ for electrophysiological and morphological experiments, respectively.

The cocultures were maintained in water-saturated atmosphere $(95 \%$ air $/ 5 \% \mathrm{CO}_{2}$ ) at $37^{\circ} \mathrm{C}$. Medium was renewed for the first time after $5 \mathrm{~d}$ and subsequently every $3 \mathrm{~d}$.

\section{Immunocytochemistry}

After 5, 8, or $12 \mathrm{~d}$ in vitro (DIV), cultures were fixed for $10 \mathrm{~min}$ at room temperature in PBS containing 4\% paraformaldehyde (Eastman Kodak, Rochester, NY) and subsequently rinsed with PBS.

To perform the double immunostaining of glutamic acid decarboxylase (GAD) and $\alpha-\mathrm{MSH}$, cultures were incubated overnight at $4^{\circ} \mathrm{C}$ with a rabbit polyclonal antibody against GAD (1:500; antibody 108, Chemicon, Temecula, CA), rinsed three times with PBS, incubated for $1 \mathrm{hr}$ at room temperature in biotinylated goat anti-rabbit IgG (1:500; Vector Laboratories), and subsequently for $1 \mathrm{hr}$ with an avidin-biotin-peroxidase complex (Elite kit, Vector). After three washes, immunoreactivity was detected with 3,3'diaminobenzidine tetrahydrochloride (Vectastain kit, Vector). Reaction was stopped by washing with PBS. Then cultures were incubated $1 \mathrm{hr}$ at $37^{\circ} \mathrm{C}$ with a rabbit antiserum against $\alpha$-MSH (1:3000; from the late Dr. G. Schmidt, Strasbourg, France). After antibody incubation, the cocultures were rinsed three times with PBS, incubated for 1 $\mathrm{hr}$ at room temperature with fluorescein isothiocyanate (FITC)conjugated anti-rabbit IgG (1:200; Biosys), and mounted in antifading mounting medium (Biosys) after additional rinsing with PBS.

In the experiments in which double immunostaining against synapsin I and $\alpha$-MSH was performed, the staining for $\alpha$-MSH was done first, according to the protocol described in the preceding paragraph. After rinsing, the cocultures were incubated overnight (at room temperature) in rabbit polyclonal antibody directed against bovine synapsin I (1:500; from Dr. J. Baudier, Strasbourg, France) and diluted in PBS containing $0.1 \%$ Triton X-100. In Western blot analysis of rat cortical neurons, the synapsin antibody that was used revealed only two bands ( 80 and $86 \mathrm{kDa})$ corresponding to the isoforms (data not shown) as described by De Camilli et al. (1983). After three washes in PBS containing 0.1\% Triton $\mathrm{X}-100$, the cocultures were incubated for $1 \mathrm{hr}$ at room temperature with FITC-conjugated anti-rabbit IgG (1:200; Biosys) and mounted in antifading mounting medium after additional rinsing with PBS.

\section{Electron microscopy}

Cultures grown for 8 and 12 DIV on glass coverslips were fixed with 5\% glutaraldehyde (Fluka, Buchs, Switzerland) in phosphate buffer $(0.1 \mathrm{M}$, $\mathrm{pH}$ 7.4) for $1 \mathrm{hr}$ at $4^{\circ} \mathrm{C}$ and post-fixed during $1 \mathrm{hr}$ with $1 \%$ osmium tetroxide in phosphate buffer containing $1.6 \%$ potassium ferrocyanide. After dehydration in graded alcohols, the preparation was flat-embedded in an Araldite-Epon mixture. The coverslips were detached by immersion in liquid nitrogen. Thin sections (500 $)$ ), contrasted with uranyl acetate and lead citrate, were examined under a Jeol $100 \mathrm{CX}$ electron microscope (Tokyo, Japan).

\section{Electrophysiological recordings}

Experiments were performed at room temperature $\left(20-22^{\circ} \mathrm{C}\right), 6-14 \mathrm{~d}$ after plating of the cells. Patch-clamp recordings were made in the whole-cell configuration (Hamill et al., 1981) with an Axopatch 200A amplifier (Axon Instruments, Foster City, CA) and low resistance (3-4 $\mathrm{M} \Omega$ ) electrodes. If not otherwise stated, the standard external medium contained (in mM): $\mathrm{NaCl} 135, \mathrm{KCl} 5, \mathrm{CaCl}_{2} 5, \mathrm{MgCl}_{2}$ 1, HEPES 5, and glucose $10, \mathrm{pH} 7.3$ (adjusted with $\mathrm{NaOH}$ ). In some experiments, the external calcium concentration was reduced to 2.5 or $0.3 \mathrm{~mm}$. In the latter case, the magnesium concentration was raised to $10 \mathrm{~mm}$. Finally, in experiments using a calcium-free extracellular medium, calcium ions were totally replaced by magnesium, and $1 \mathrm{~mm}$ EGTA was added. Pipettes were filled with an intracellular solution containing (in $\mathrm{mM}$ ): $125 \mathrm{KCl}$ or $\mathrm{CsCl}, 5 \mathrm{CaCl}_{2}, 2 \mathrm{MgCl}_{2}, 10$ HEPES, 10 EGTA, and $2 \mathrm{Na}_{2}$-ATP, pH 7.3 (adjusted with $\mathrm{KOH}$ or $\mathrm{CsOH}$ ). The estimated intracellular-free calcium concentration was $10^{-7} \mathrm{M}$, and the equilibrium potential for chloride ions $\left(E_{\mathrm{Cl}}\right)$ was $-2 \mathrm{mV}$. In experiments in which $E_{\mathrm{Cl}}$ was shifted to $-40 \mathrm{mV}$, we used an intracellular solution containing (in $\mathrm{mM}$ ): $17 \mathrm{CsCl}, 54 \mathrm{Cs}_{2} \mathrm{SO}_{4}, 5$ $\mathrm{CaCl}_{2}, 2 \mathrm{MgCl}_{2}, 10$ HEPES, 10 EGTA, and $2 \mathrm{Na}_{2}$-ATP, pH 7.3 (adjusted with $\mathrm{KOH}$ or $\mathrm{CsOH}$ ).

Drugs were diluted in the external medium and were applied by local perfusion with a "U-tube" (Fenwick et al., 1982). The external high potassium solution $(50 \mathrm{mM}$ ) was prepared by substituting $45 \mathrm{~mm} \mathrm{NaCl}$ of the standard extracellular solution with $45 \mathrm{~mm} \mathrm{KCl}$. Kainate (Tocris Neuramin), bicuculline (Sigma), SR95531 (gift of Sanofi-Recherche), and tetrodotoxin (TTX; Latoxan) were prepared as $100-1000 \times$ concentrated stock solutions in distilled water and stored at $-20^{\circ} \mathrm{C} . \mathrm{LaCl}_{3}$ was prepared at $100 \mathrm{~mm}$ in distilled water and stored at $4^{\circ} \mathrm{C}$. The solutions to be tested were dissolved at final concentration in extracellular solution just before the recording session.

\section{Electrical stimulation}

Electrical stimulation was applied to the cell body of the presynaptic neuron with two patch pipettes filled with extracellular solution (resistance $\leq 1 \mathrm{M} \Omega$ ) and glued tip to tip under a stereomicroscope with dental wax. The tips of the two pipettes usually were separated by $<50 \mu \mathrm{m}$. The electrodes were connected to the output of a pulse generator (one electrode to the positive output and the other to the negative output). The duration of the stimuli was $0.1 \mathrm{msec}$ in all experiments, and the stimulation intensity that was used varied between -10 and $-20 \mathrm{~V}$. The stimulation electrodes were lowered onto the neuron after the whole-cell recording configuration had been established in the postsynaptic (pituitary) cell; one of them was placed in direct contact with the cell soma of the visually identified presynaptic neuron. In these experiments, we selected isolated pairs of cells exclusively, i.e., a melanotroph that was in contact with a single neurite of a single presynaptic neuron.

\section{Data storage and analysis}

Synaptic currents were stored on videotape under digital form $(20 \mathrm{kHz})$ after being filtered at $5 \mathrm{kHz}$ by the internal filter of the Axopatch $200 \mathrm{~A}$ amplifier. Analysis was performed with Axograph II software (Axon Instruments) on a Macintosh IIvx computer. So that the decay phases of synaptic currents could be analyzed, the current traces were filtered at 2 $\mathrm{kHz}$ and digitized at $4 \mathrm{kHz}$ with pClamp software (Fetchex, Axon Instruments). These parameters were used routinely after it was verified that filtering and digitizing at higher frequencies gave similar results. However, analysis of the rise times and the amplitudes were performed on current traces that were acquired directly from the videotape without additional filtering and digitized at $10 \mathrm{kHz}$. Digitization at higher frequencies (e.g., $50 \mathrm{kHz}$ ) produced similar results. Rise times and amplitudes of the synaptic currents were measured manually by using the cursor measurement facility of the Axograph software. Automated measurement of amplitudes produced comparable results. Rise times were 

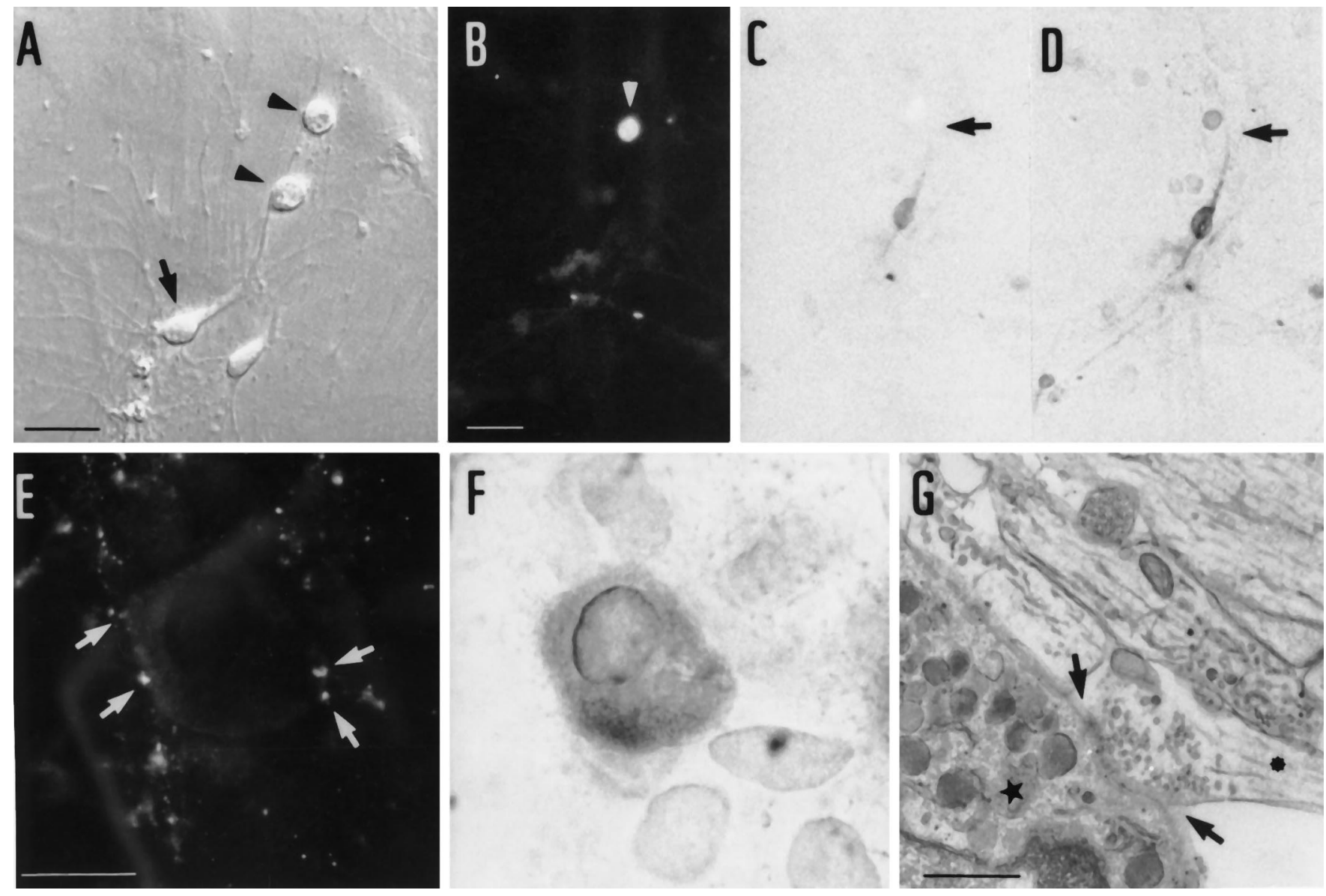

Figure 1. A, Micrograph taken under Hoffman interference contrast showing hypothalamic neurons from embryonic day 15 rat embryos cocultured with melanotrophs for $8 \mathrm{~d}$. Neurons have extended neurites, whereas melanotrophs are spherical and devoid of any processes. Note the presence of a neuron (arrow) that sends a thin neurite, establishing apparent contacts with two melanotrophs (arrowheads). Scale bar, $20 \mu \mathrm{m}$. B-D, Double labeling $\mathrm{GAD} / \alpha$-MSH after $8 \mathrm{~d}$ in vitro (8 DIV); $\alpha$-MSH is revealed by immunofluorescence and GAD by immunoperoxidase. Same field viewed under ultraviolet (UV) illumination $(B)$, both UV and visible light illumination $(C)$, and visible light only $(D)$. A GAD ${ }^{+}$neuron enters in contact with a melanotroph (white arrowheads) via a thin, weakly labeled neurite (black arrows). Scale bar, $20 \mu \mathrm{m}$. $E, F$, Double immunostaining against $\alpha$-MSH and synapsin I after 8 DIV. Synapsin I is revealed by immunofluorescence $(E)$ and $\alpha$-MSH by immunoperoxidase $(F)$. Strongly labeled punctae of synapsin I (white arrows) are apposed to a melanotroph immunoreactive for $\alpha$-MSH. Scale bar, $10 \mu \mathrm{m}$. $G$, Electron micrograph showing synaptic differentiations at the level of a neuroglandular contact (black arrows) at 12 DIV. Note the accumulation of synaptic vesicles in the nerve terminal that is presynaptic to the melanotroph (black star). Scale bar, $0.5 \mu \mathrm{m}$.

expressed as the total duration of the rising phase from baseline $(0 \%)$ to the peak (100\%) of the synaptic current. Exponential fits of the decaying phases of the synaptic currents were performed with the internal-fitting routines of the Axograph software. All statistical results are expressed as mean $\pm \mathrm{SD}$.

The electrophysiological results presented in this report were obtained from 180 pituitary cells ( 28 different cocultures) that had received synaptic input from hypothalamic neurons grown with them in dissociated coculture.

\section{RESULTS}

\section{Morphological characteristics of hypothalamo-hypophyseal cocultures}

After $24 \mathrm{hr}$ in vitro, different cell populations were distinguishable on the basis of their morphological appearance. Melanotrophs were devoid of any processes, conserved a typical phase-bright and spherical appearance, and displayed strong immunoreactivity to $\alpha$-MSH (Fig. $1 B, F$ ) throughout the culture period. The hypothalamic neurons had an ovoid cell body and started rapidly (within a few hours) to extend one or two thin short processes. Concomitantly, they began to establish apparent contacts with each other. The diameters of their cell bodies were smaller $(<10$ $\mu \mathrm{m})$ than that of melanotrophs $(10-12 \mu \mathrm{m})$. After $3 \mathrm{DIV}$, all neuronal cells had grown processes, and a complex fiber network was formed. Neurons positively stained by an antibody directed against $\mathrm{GAD}^{+}$represented $83.8 \pm 6.2 \%(n=9)$ of the total neuronal population. It was possible to identify apparent contacts between the neurites of individual neurons and melanotrophs (Figs. $1 A, 2 C$ ). Virtually all neurons establishing such apparent contacts with melanotrophs were $\mathrm{GAD}^{+}$(Fig. $\left.1 B-D\right)$.

After 8 DIV, synapsin I immunoreactivity was highly concentrated in tiny dots scattered on less intensely labeled neuronal cell bodies and processes (data not shown). Using a synapsin I/ $\alpha$-MSH double-immunolabeling technique, we identified synapsin I punctae (Fig. $1 E$ ) in close apposition with melanotrophs (Fig. $1 F$ ), suggesting the formation of synaptic contacts between the two cell populations. At this stage of development, $8 \mathrm{DIV}$, observation of cocultures under electron microscopy clearly revealed the presence of neuroneuronal and neuroendocrine contacts exhibiting synaptic specializations (Fig. $1 G$ ), i.e., clustering of synaptic vesicles in the presynaptic element and the presence of pre- and postsynaptic densities. 

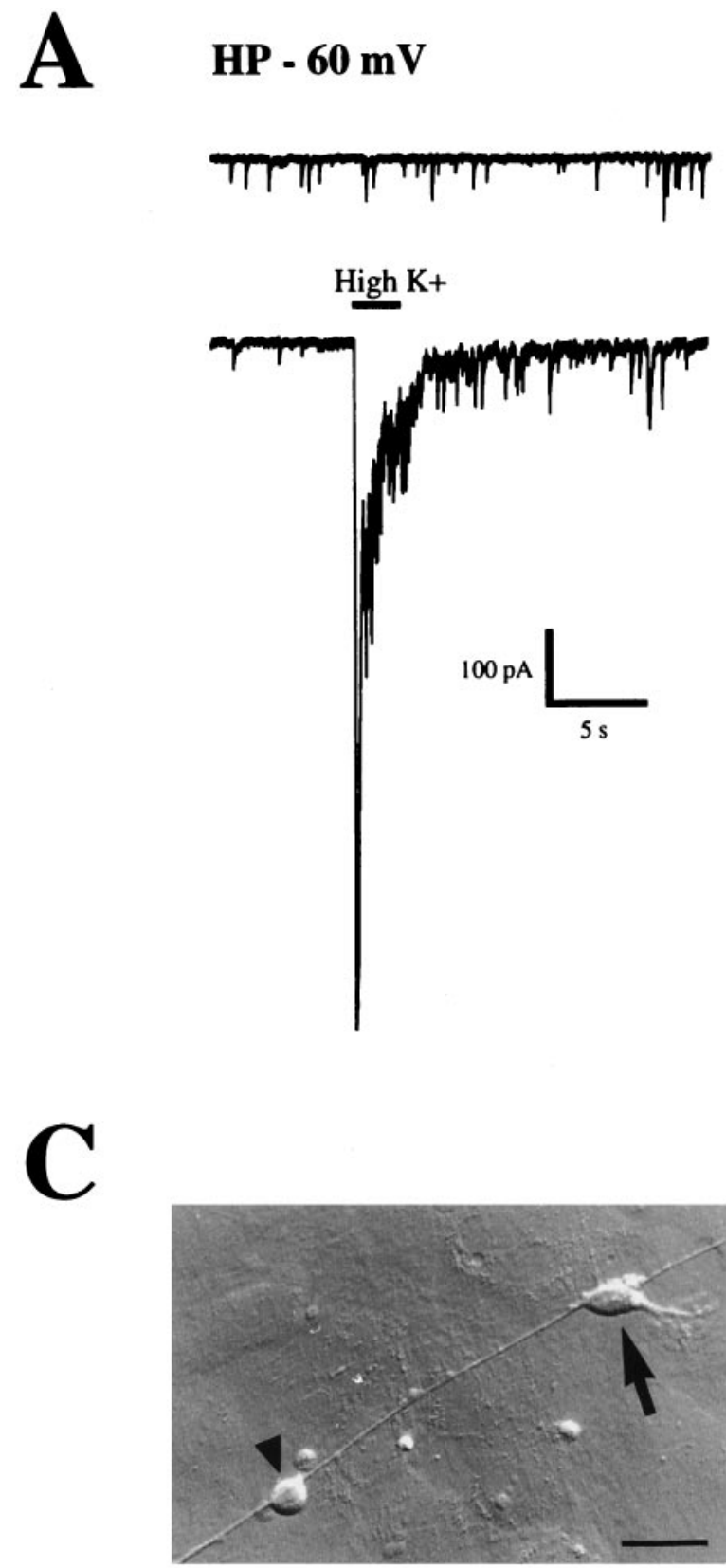

B HP - $60 \mathrm{mV}$
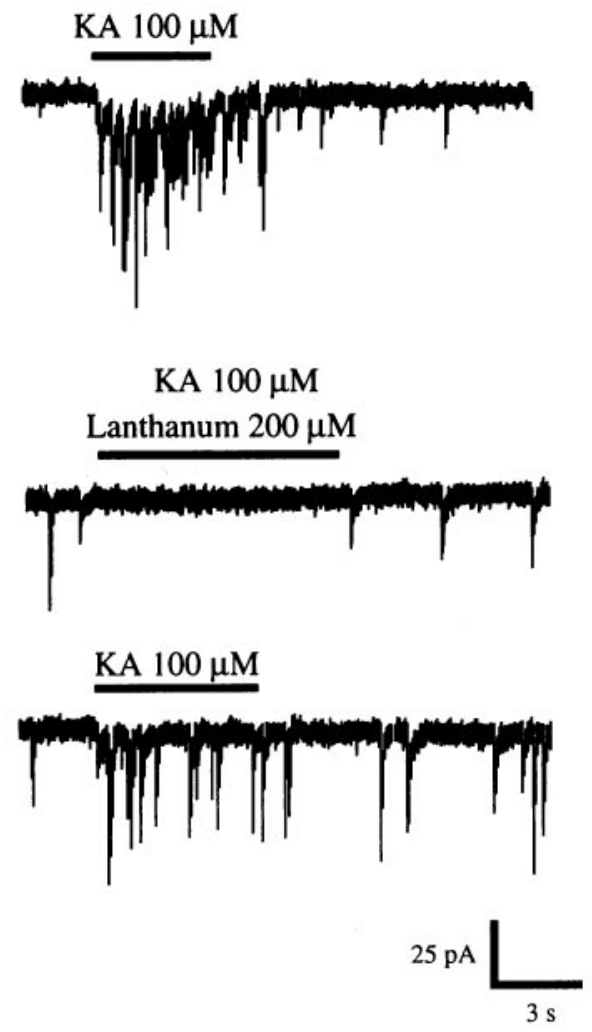

D

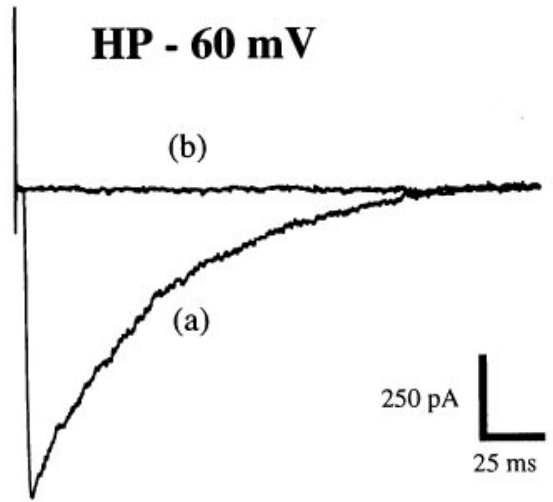

Figure 2. Synaptic events recorded in melanotrophs can be evoked by chemical and electrical stimulation. A, Top trace, Example of spontaneous synaptic currents that were recorded as randomly occurring, transient inward currents under voltage clamp. The holding potential $(H P)$ was maintained at -60 $\mathrm{mV}$. Bottom trace, Local application of an extracellular solution containing $50 \mathrm{KCl}$, for the duration indicated by the horizontal bar, triggered an inward current that was associated with an increase in the frequency of the synaptic events. Note that this latter phenomenon outlasted the inward current induced by the high $\mathrm{K}^{+}$solution. $B$, Application of kainate (KA) at a concentration of $100 \mu \mathrm{M}$ also stimulated the frequency of synaptic currents. This stimulatory effect of KA was blocked completely and reversibly by lanthanum ions $\left(\mathrm{La}^{3+} ; 200 \mu \mathrm{M}\right)$, which block voltage-dependent $\mathrm{Ca}^{2+}$ currents. The $\mathrm{HP}$ was -60 $\mathrm{mV}$. C, Example of a hypothalamic neuron (arrow) contacting a single melanotroph (arrowhead). Electrical stimulation was performed exclusively on isolated pairs of cells. Scale bar, $20 \mu \mathrm{m}$. $D$, Direct extracellular stimulation of the cell body of the presynaptic neuron (see Materials and Methods) with negative current induced a large IPSC (trace $a$ ), whereas positive current of the same amplitude failed to evoke an IPSC (trace $b$ ).

\section{Electrophysical characterization of functional synaptic contacts between hypothalamic neurons and melanotrophs}

To determine whether the contacts established between GABAergic hypothalamic neurons and melanotrophs corresponded to functional synapses, we used the whole-cell configuration of the patch-clamp technique to record from melanotrophs in contact with a neurite of a hypothalamic neuron.
Spontaneous synaptic activity was recorded in 19 of 83 melanotrophs $(22.9 \%)$ receiving synaptic input from hypothalamic neurons. In cells displaying no spontaneous synaptic activity, the presence of functional synaptic contacts was determined by applying locally a solution containing $50 \mathrm{~mm} \mathrm{KCl}$, which stimulates the release of a neurotransmitter by triggering $\mathrm{Ca}^{2+}$ influx in the presynaptic terminal (Fig. 2A). Application of the high $\mathrm{K}^{+}$solution induced an inward current in the postsynaptic cell (attribut- 

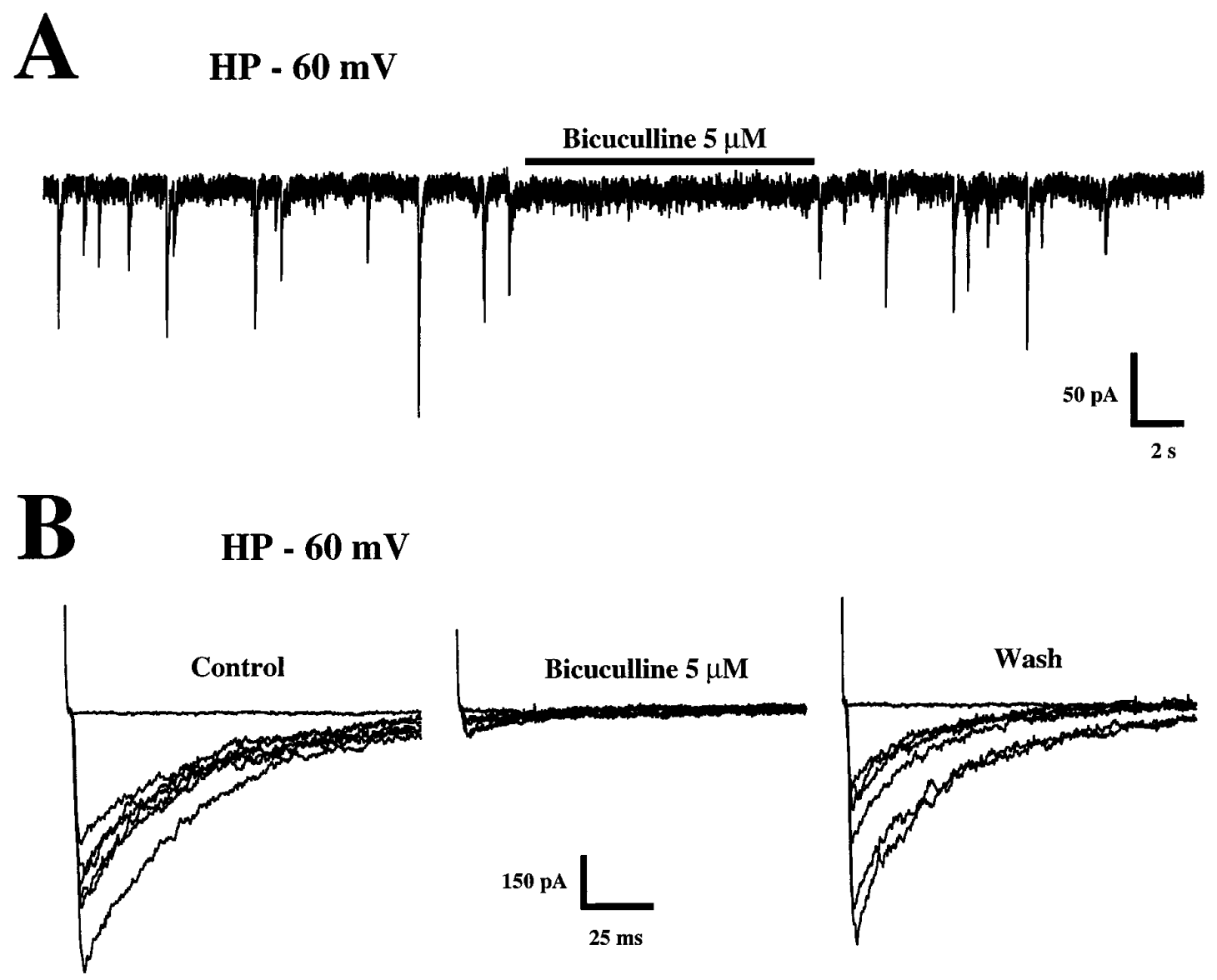

Figure 3. The synaptic currents are mediated by $\mathrm{GABA}_{\mathrm{A}}$ receptors. $A$, Bicuculline $(5 \mu \mathrm{M})$, a competitive antagonist of the GABA $\mathrm{G}_{\mathrm{A}}$ receptor, induced a complete and reversible block of spontaneous synaptic currents. The HP was $-60 \mathrm{mV}$, and bicuculline was applied locally for the duration indicated by the horizontal bar. B, The synaptic currents evoked by electrical stimulation also were inhibited reversibly by bicuculline ( $5 \mu \mathrm{M})$, suggesting that they were GABAergic.

able to a positive shift of the $\mathrm{K}^{+}$equilibrium potential during the application) and a marked increase in the frequency of synaptic events, which outlasted the application of $\mathrm{K}^{+}$for $1-2 \min (n=$ 19). In cells displaying no spontaneous activity, the high $\mathrm{K}^{+}$ solution induced synaptic activity that persisted for 1-2 min after the application $(n=64)$. As shown in Figure $2 B$, application of the non-NMDA excitatory amino acid receptor-agonist kainic acid (KA; $100 \mu \mathrm{M})$ mimicked the effect of high $\mathrm{K}^{+}$on synaptic activity $(n=13)$. However, KA did not trigger a macroscopic inward current in the postsynaptic neuroendocrine cell, suggesting that the site of action of KA was presynaptic. The absence of effect of KA at the postsynaptic level was confirmed by the fact that KA $(100-200 \mu \mathrm{M})$ did not induce any inward current at a holding potential (HP) of $-60 \mathrm{mV}$ when applied on isolated melanotrophs in primary culture $(n=16)$. However KA $(100-200 \mu \mathrm{M})$ induced large, nondesensitizing inward currents in all hypothalamic neurons tested ( $n=20$; data not shown).

The stimulatory effect of the high $\mathrm{K}^{+}$solution on synaptic activity was blocked when all external $\mathrm{Ca}^{2+}(5 \mathrm{mM})$ was replaced by $10 \mathrm{mM} \mathrm{Mg}^{2+}$ in the presence of $1 \mathrm{~mm}$ of the $\mathrm{Ca}^{2+}$ chelator EGTA $(n=6)$, suggesting that the effect of high $\mathrm{K}^{+}$was $\mathrm{Ca}^{2+}$ dependent. In line with this, $\mathrm{La}^{3+}(200 \mu \mathrm{M})$, which blocks voltagedependent $\mathrm{Ca}^{2+}$ currents, blocked totally and reversibly the increase in synaptic activity induced by $100-200 \mu \mathrm{M} \mathrm{KA}(n=6$; Fig. $2 B$ ). We have used $\mathrm{La}^{3+}$ ions, because most divalent cations that currently are used to block $\mathrm{Ca}^{2+}$ currents also block $\mathrm{GABA}_{\mathrm{A}}$ receptor-gated $\mathrm{Cl}^{-}$currents (Kaneko and Tashibana, 1986). In contrast, $\mathrm{La}^{3+}$ ions are known to potentiate, rather than to block, $\mathrm{GABA}_{\mathrm{A}}$ currents (Ma and Narahashi, 1993) and therefore make it possible to distinguish between a presynaptic effect (block of $\mathrm{Ca}^{2+}$ channels) and a postsynaptic effect of these ions.

To study in more detail the synaptic transmission between pairs of cells, we have stimulated extracellularly the presynaptic neuron while recording from the postsynaptic pituitary cell. In this set of experiments, we selected exclusively melanotrophs being contacted by a single neurite from a visually identified neuron (Fig. 2C,D).

\section{The synaptic currents are mediated by $\mathrm{GABA}_{\mathrm{A}}$ receptors}

The competitive $\mathrm{GABA}_{\mathrm{A}}$ receptor antagonist bicuculline $(5 \mu \mathrm{M})$ reversibly inhibited both the spontaneous $(n=18$; Fig. $3 A)$ and electrically evoked $(n=9$; Fig. $3 B)$ synaptic currents. SR95531 (5 $\mu \mathrm{M})$, an even more selective competitive antagonist of $\mathrm{GABA}_{\mathrm{A}}$ receptors (Hamann et al., 1988), also blocked in a reversible manner both spontaneous $(n=5)$ and electrically evoked $(n=5)$ synaptic activities.

These results suggested that the synaptic currents are attributable to the activation of $\mathrm{GABA}_{\mathrm{A}}$ receptors, which are $\mathrm{Cl}^{-}$permeable ion channels (MacDonald and Olsen, 1994). In line with this, the spontaneous synaptic currents reversed polarity at a potential of $\sim 0 \mathrm{mV}(n=14)$, a value that was close to the 


\section{A HP. $60 \mathrm{mv}$

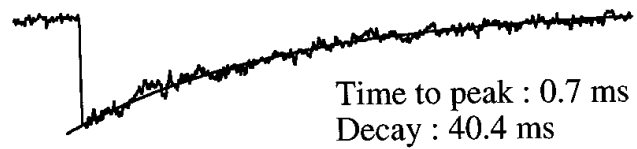

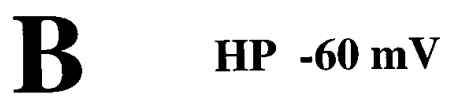

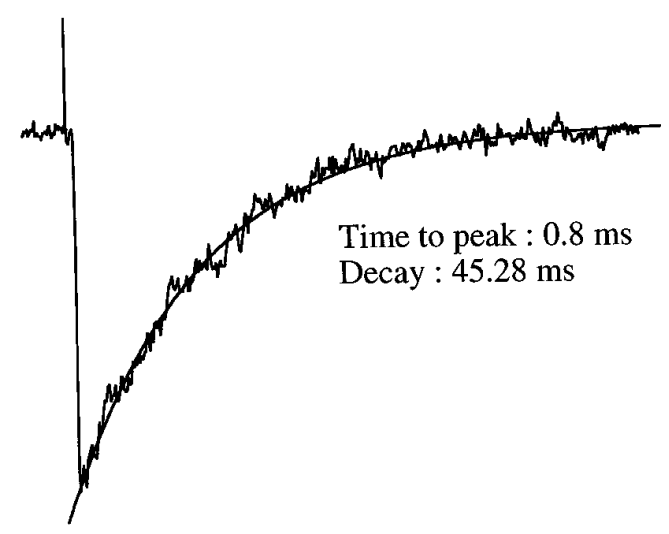

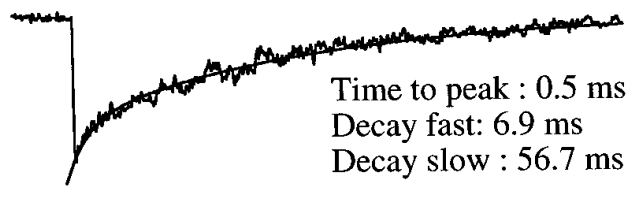

20 pA

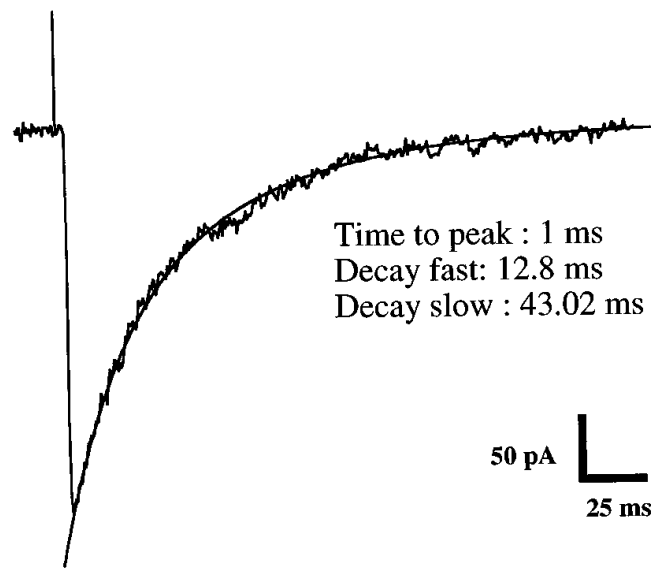

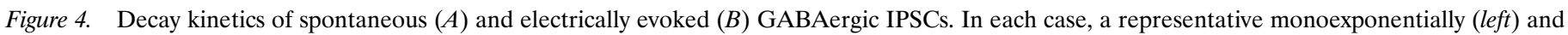

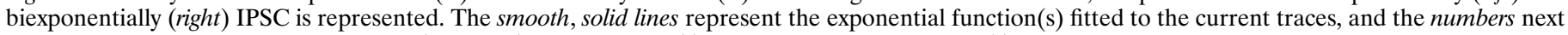
to each trace indicate the time to peak (rise time) and the value(s) of the decay time constant(s).

equilibrium potential for $\mathrm{Cl}^{-}$ions in our standard recording conditions $(-2 \mathrm{mV})$. Moreover, when $E_{\mathrm{Cl}}$ was set at $-40 \mathrm{mV}$ by lowering the concentration of $\mathrm{Cl}^{-}$in the pipette solution (see Materials and Methods), the reversal potential of the synaptic currents followed the theoretical value of $E_{\mathrm{Cl}}(n=3)$. The current-voltage $(I-V)$ relationship of electrically evoked synaptic currents was linear, displaying no marked rectification over the membrane potential range tested $(-60$ to $+40 \mathrm{mV})$. The mean reversal potential of these electrically evoked synaptic currents was $0.41 \pm 4.3 \mathrm{mV}(n=5)$, which was close to $E_{\mathrm{Cl}}(-2 \mathrm{mV})$.

These results suggested that the synaptic events were mediated by a $\mathrm{GABA}_{\mathrm{A}}$ receptor-gated chloride conductance and therefore represented GABAergic IPSCs. In the following sections, we will refer to the spontaneous and electrically evoked synaptic currents as s-IPSCs and ee-IPSCs, respectively.

\section{Kinetic properties of GABAergic IPSCs}

The mean rise times of synaptic currents were $0.71 \pm 0.18 \mathrm{msec}$ for s-IPSCs $(n=28)$ and $1.1 \pm 0.13 \mathrm{msec}$ for ee-IPSCs $(n=$ 10). The kinetic properties of the deactivation phase of the IPSCs were independent of the amplitudes of these currents. Analysis of individual (i.e., nonaveraged) current traces revealed that, in a given cell, the decaying phases of $\sim 90 \%$ of the s-IPSCs could be fitted with a single exponential function, whereas the remaining $10 \%$ of the events needed two exponential functions to describe the decaying phase (Fig. 4). The mean proportion of s-IPSCs with a monoexponential decaying phase in different cells was $88 \pm 8 \%(n=28)$. Biexponentially decaying s-IPSCs occurred randomly during the recording period, and there was no correlation between the biexponential nature of the deactivation phase and the amplitude of the s-IPSC. However, as pointed out by Borst et al. (1994) in their study on GABAergic transmission in bullfrog melanotrophs, the biexponential nature of the IPSC decaying phase is more difficult to detect in the case of small synaptic currents, such as s-IPSCs (see Figs. 5, 6), compared with currents of larger size, such as ee-IPSCs (see Fig. 7). In line with this, we found that $29.4 \pm 17.3 \%(n=11$ different cells $)$ of ee-IPSCs displayed biexponential decaying phases, the fast component representing $40.7 \pm 11.4 \%$ of the peak amplitude of the IPSC.

At an $\mathrm{HP}$ of $-60 \mathrm{mV}$, the mean deactivation time constant for monoexponential decaying synaptic currents was $45 \pm 16 \mathrm{msec}$ ( $n=28$ cells) for s-IPSCs and $49.3 \pm 3 \mathrm{msec}(n=10)$ for ee-IPSCs (Fig. $4 A, B$ ). For the synaptic events showing a biexponential decay phase, the time constants were $4.5 \pm 3.2$ and $53 \pm$ $17 \mathrm{msec}(n=28$ cells $)$ for s-IPSCs and $9.2 \pm 3.8$ and $69.5 \pm 18.9$ msec $(n=10)$ for ee-IPSCs (Fig. $4 A, B)$.

As described for GABAergic IPSCs in other preparations, membrane depolarization induced a slowing of the deactivation phase, i.e., an increase in the value of decay time constant. For example, the mean time constants of monoexponentially decaying IPSCs were $47.7 \pm 11.8 \mathrm{msec}(\mathrm{s}-\mathrm{IPSCs}, n=10$ ) and $53.3 \pm 3.1$ msec (ee-IPSCs, $n=6$ ) at an HP of $-60 \mathrm{mV}$ and $87.2 \pm 21.1 \mathrm{msec}$ (s-IPSCs, $n=10$ ) and $103.9 \pm 30.0 \mathrm{msec}($ ee-IPSCs, $n=6$ ) at an $\mathrm{HP}$ of $+40 \mathrm{mV}$. In contrast, the value of the rise time of s-IPSCs 

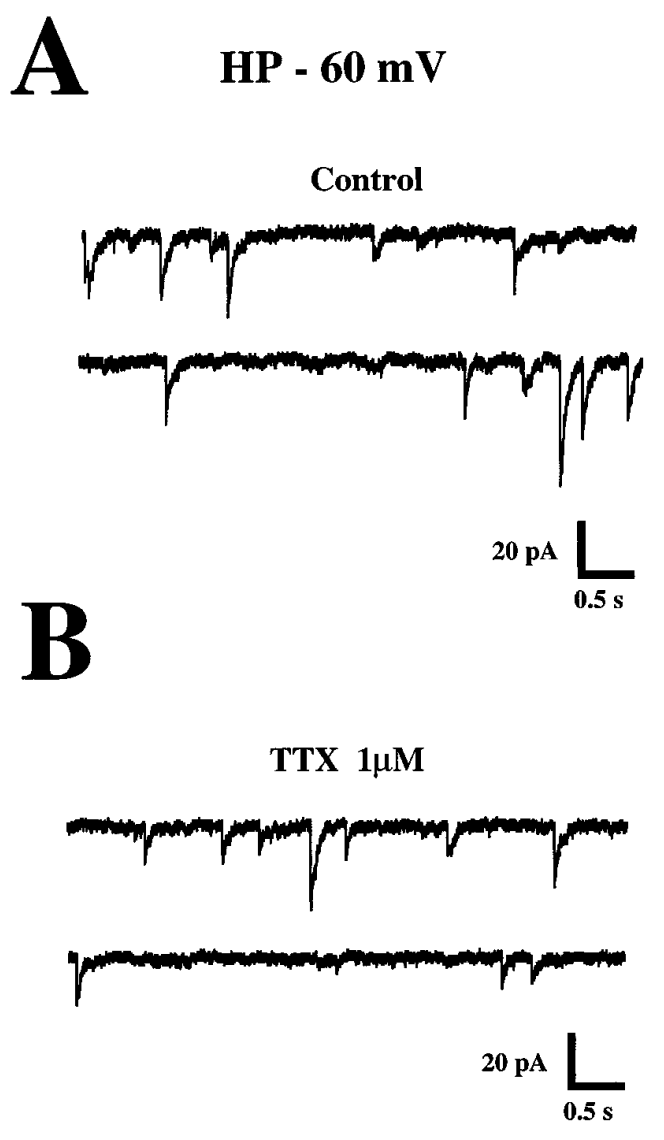
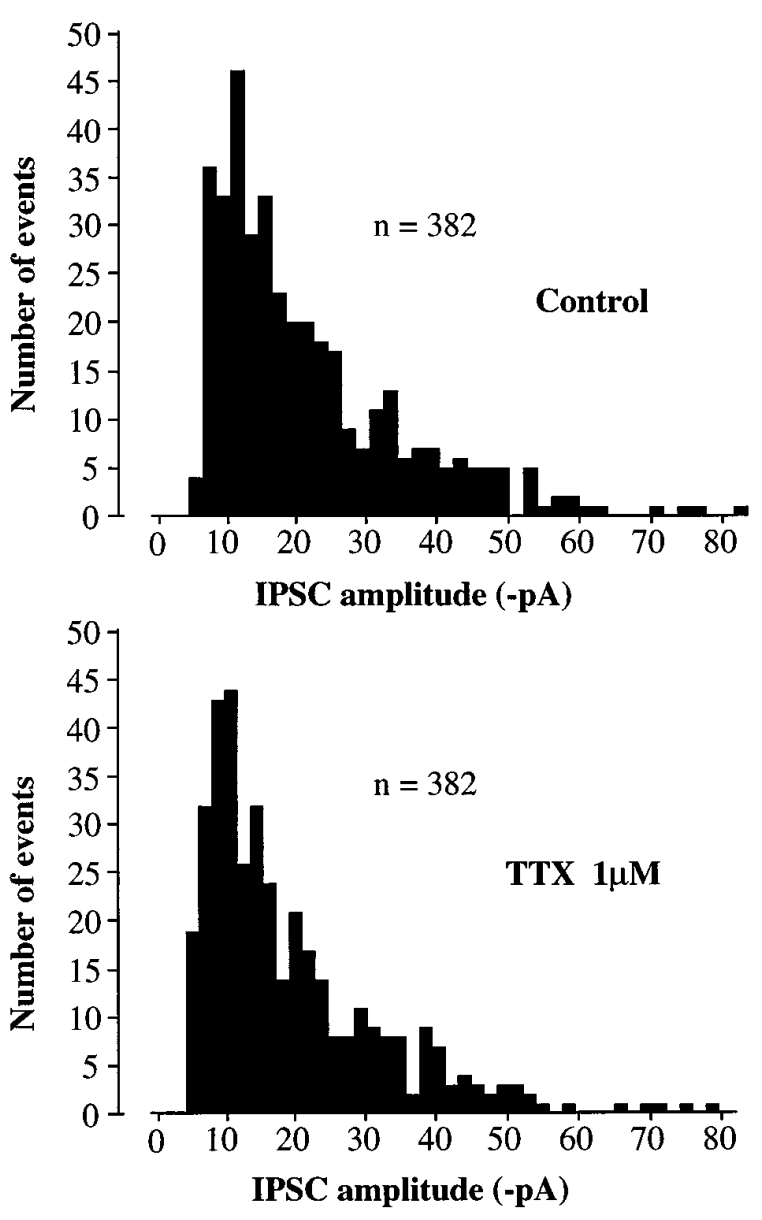

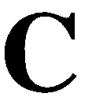

\section{$\mathrm{HP}$ - $60 \mathrm{mV}$}
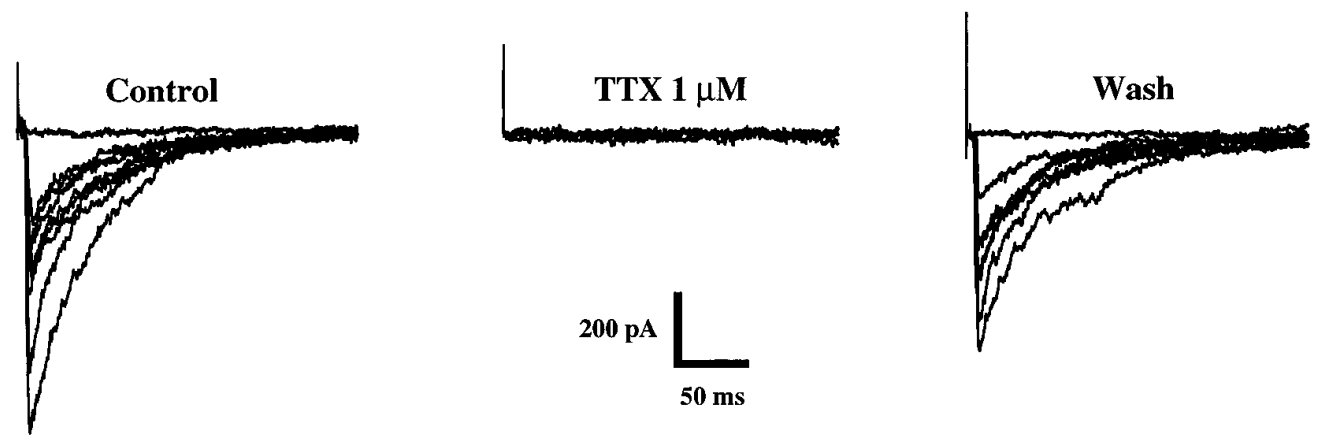

Figure 5. Effect of tetrodotoxin (TTX; $1 \mu \mathrm{M})$ on spontaneous and electrically evoked IPSCs. $A$, Example of IPSCs recorded in control medium (left) and the corresponding amplitude histogram (right). B, Current traces showing s-IPSCs recorded in the presence of $1 \mu \mathrm{M}$ TTX (left) and corresponding amplitude histogram (right). Both histograms were constructed with the same number of events $(n=382)$, and the data in $A$ and $B$ are from the same cell. Note that TTX did not markedly affect the frequency of s-IPSC or the overall amplitude distribution, suggesting that most s-IPSCs resulted from miniature synaptic currents. $C$, In contrast to s-IPSCs, electrically evoked IPSCs were blocked totally and reversibly by $T T X$ (1 $\mu \mathrm{M})$. Bin width, 2 pA.

$(n=10)$ and ee-IPSCs $(n=6)$ did not change with membrane potential.

\section{Properties of miniature IPSCs and their calcium dependence}

Amplitude histograms of s-IPSCs, such as that illustrated in Figure $5 A$, were constructed for nine cells at an HP of $-60 \mathrm{mV}$. Most of the s-IPSCs ( $>95 \%)$ had amplitudes smaller than $100 \mathrm{pA}$, and the distribution of their amplitudes did not reveal clear, apparent, and equidistant peaks. This observation, however, does not necessarily imply that the synaptic transmission in our preparation is not quantal (Edwards, 1995; Isaacson and Walmsley, 1995), because similar findings have been reported for many central synapses displaying quantal properties (Bekkers, 1994; Edwards, 1995).

To look for quantal aspects of the GABAergic transmission in our system, we have examined the amplitude distribution of 


\section{A}

\section{HP - $60 \mathrm{mV}$}

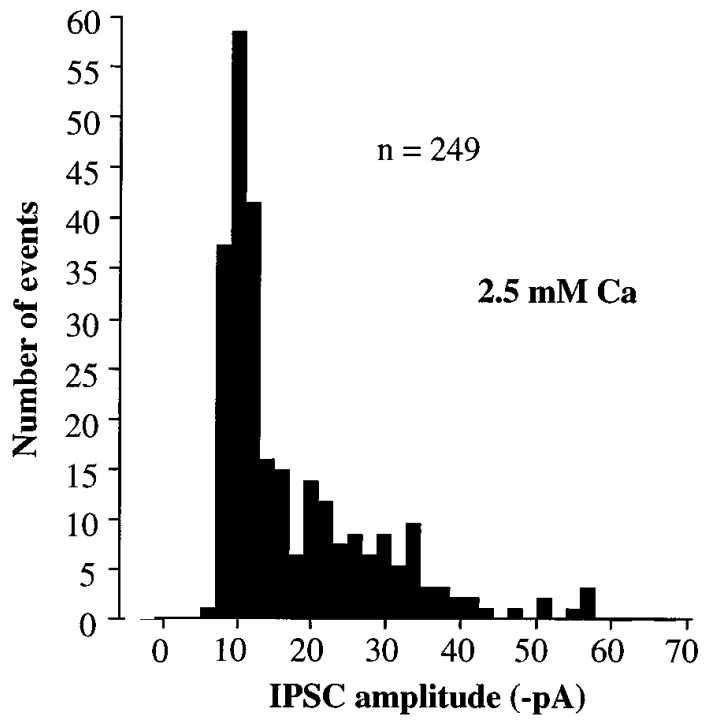

B

HP - $60 \mathrm{mV}$

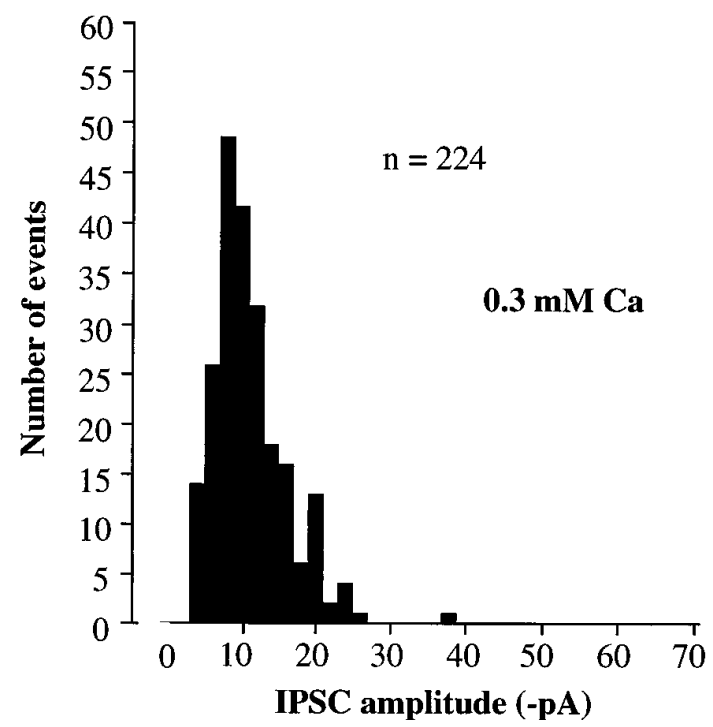

Figure 6. Amplitude distribution of s-IPSCs at two different extracellular $\mathrm{Ca}^{2+}$ concentrations. $A, \mathrm{Ca}^{2+}(2.5 \mathrm{~mm} ; n=249$ events $) . B, \mathrm{Ca}^{2+}\left(0.3 \mathrm{mM} ; \mathrm{Mg}^{2+}\right.$ concentration raised to $10 \mathrm{mM} ; n=224$ events). Note that at low extracellular $\mathrm{Ca}^{2+}$ concentration $(0.3 \mathrm{~mm})$ a single peak at $10 \mathrm{pA}$ is observed and represents the amplitude of the miniature IPSC at a holding potential $(H P)$ of $-60 \mathrm{mV}$.

s-IPSCs in (1) a normal extracellular medium containing TTX to block presynaptic $\mathrm{Na}^{+}$-dependent action potentials and (2) extracellular solutions containing lower concentrations of $\mathrm{Ca}^{2+}(2.5$ and $0.3 \mathrm{~mm}$ ) to reduce the release probability of synaptic vesicles.

\section{Effect of $T T X$}

Superfusion of the cells with a standard medium containing $1 \mu \mathrm{M}$ TTX to block presynaptic action potentials and to isolate miniature IPSCs (m-IPSCs) did not affect significantly the frequency or the kinetic properties of s-IPSCs. In eight cells tested, the mean frequency, rise time, and decay time constant were $0.24 \pm 0.12 \mathrm{~Hz}$, $0.69 \pm 0.05 \mathrm{msec}$, and $45.9 \pm 9.6 \mathrm{msec}$ before TTX application and $0.25 \pm 0.2 \mathrm{~Hz}, 0.73 \pm 0.08 \mathrm{msec}$, and $44.7 \pm 7.4 \mathrm{msec}$ in the presence of TTX. TTX only slightly reduced the occurrence of the larger-sized ( $>40 \mathrm{pA}$ ) s-IPSCs (Fig. $5 B$ ). In contrast, TTX at the same concentration completely and reversibly blocked ee-IPSCs (Fig. 5C). Taken together, these observations suggested that most of the s-IPSCs were unaffected by TTX and therefore were likely to represent m-IPSCs. On the other hand, the presence of functional TTX-sensitive $\mathrm{Na}^{+}$channels was required to elicit ee-IPSCs.

\section{Effect of varying extracellular calcium concentration and quantal properties of IPSCs}

Figure 6 illustrates the amplitude distribution of s-IPSCs at two different extracellular $\mathrm{Ca}^{2+}$ concentrations. In a medium containing $2.5 \mathrm{mM} \mathrm{Ca}^{2+}$, the distribution of s-IPSC amplitudes (Fig. $6 A$ ) was similar to that obtained in a standard external medium containing $5 \mathrm{mM} \mathrm{Ca}^{2+}$ (Fig. $5 A$ ), but currents with amplitudes $>60$ pA were never recorded. Moreover, the histogram obtained in 2.5 mM Ca ${ }^{2+}$ showed a clear and prominent peak at $10 \mathrm{pA}$, which was revealed further by reducing the external $\mathrm{Ca}^{2+}$ concentration to $0.3 \mathrm{~mm}$ (Fig. 6B). Synaptic currents having amplitudes $>20 \mathrm{pA}$ were detected only rarely in low external $\mathrm{Ca}^{2+}$ (compare with Fig. $5 A$ ), and currents with amplitudes $>60 \mathrm{pA}$ were not observed.

In addition to shifting the amplitude distribution of s-IPSCs toward the smallest events $(10 \mathrm{pA})$, the reduction in external $\mathrm{Ca}^{2+}$ concentration also decreased the frequency of occurrence of $\mathrm{s}$-IPSCs. Thus, the mean frequencies of s-IPSCs recorded in extracellular solutions containing 2.5 or $0.3 \mathrm{mM} \mathrm{Ca}^{2+}$ were $0.37 \pm$ $0.23 \mathrm{~Hz}(n=8)$ and $0.08 \pm 0.02 \mathrm{~Hz}(n=6)$, respectively. The effects of different external $\mathrm{Ca}^{2+}$ concentrations on the mean s-IPSC amplitude and frequency are summarized in Table 1 . The kinetics of s-IPSCs were unchanged when the external $\mathrm{Ca}^{2+}$ concentration was reduced to $0.3 \mathrm{~mm}$.

Taken together, these findings suggest that the amplitude distribution and the frequency of occurrence of s-IPSCs depend on the concentration of external $\mathrm{Ca}^{2+}$. Moreover, our results indicate that, at a HP of $-60 \mathrm{mV}$, the unitary synaptic event (m-IPSC) induced by the release of a quantum of GABA corresponded to a current of $10 \mathrm{pA}$.

\section{Comparison of S-IPSC and ee-IPSC amplitude distribution}

As in the case of spontaneous IPSCs, the amplitudes of ee-IPSCs were variable (Fig. 7). However, in contrast to the amplitude distribution of s-IPSCs (amplitudes generally $\leq 100 \mathrm{pA}$ ), the amplitudes of ee-IPSCs were rarely $<50 \mathrm{pA}$, and currents having amplitudes up to $1 \mathrm{nA}$ could be recorded. The mean percentage of failures for ee-IPSCs, determined in 11 different cells, was $2.8 \pm 3.3 \%$ (range $0-10 \%$ ).

\section{DISCUSSION}

The aim of the present work was to describe the characteristics of a coculture system that we have developed to analyze under almost ideal conditions the formation and the functional proper- 


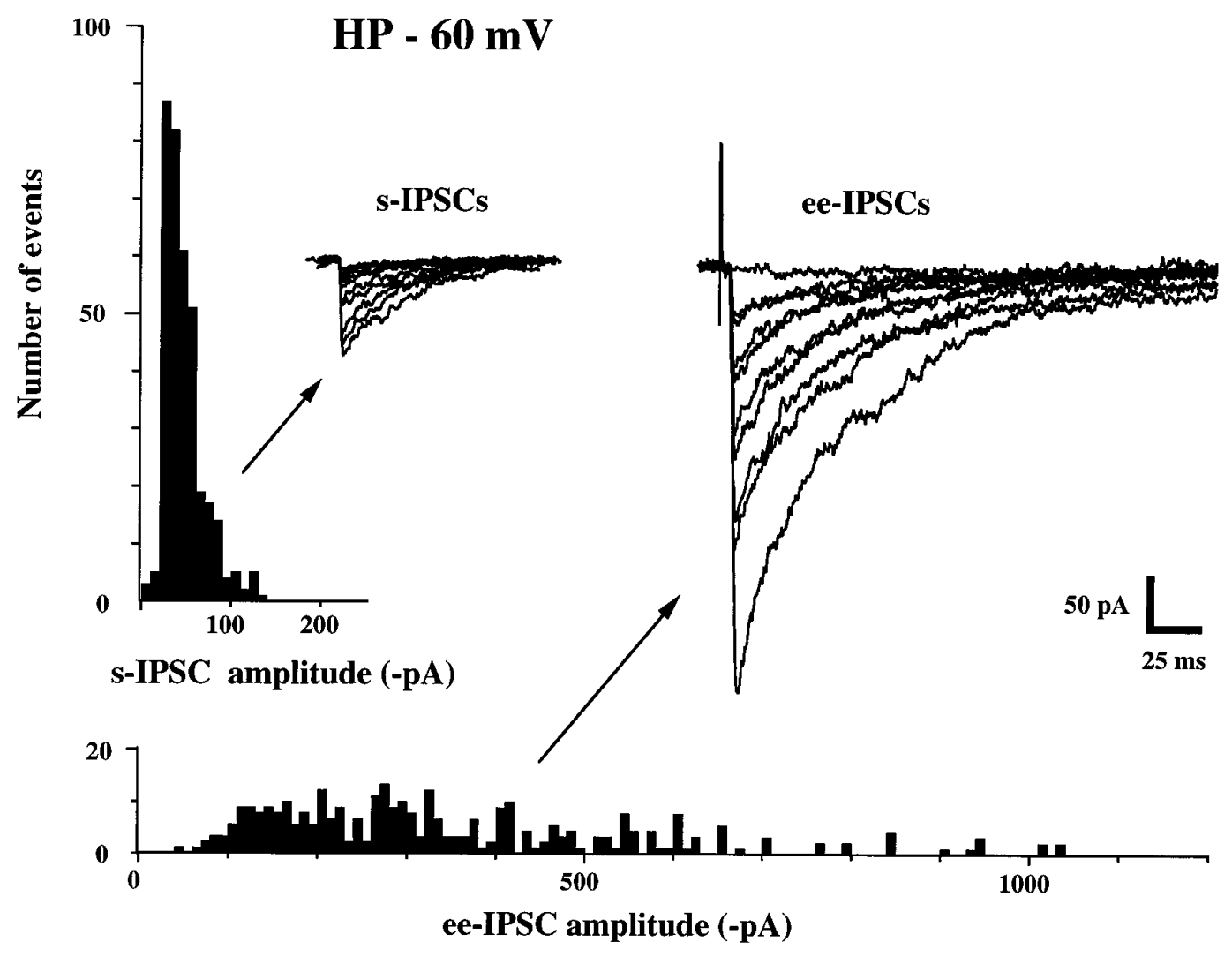

Figure 7. Amplitude distribution of spontaneous (top) or electrically evoked (bottom) GABAergic IPSCs. Insets show representative superimposed traces of spontaneous (s-IPSCs) and electrically evoked (ee-IPSCs) GABAergic synaptic currents. Note that the amplitudes of the IPSCs were variable but that the kinetic properties (rise time and exponential decay phase) were similar. The amplitudes of s-IPSCs generally comprised between 10 and 100 pA, whereas ee-IPSC amplitudes showed a much wider scattering between 50 and 1000 pA. The histogram for s-IPSCs was constructed from 382 events and that for ee-IPSCs from 233 events. Bin width for both histograms, 10 pA.

ties of synapses between a central neuron and its target. We have shown that rat hypothalamic neurons form GABAergic synapses with the endocrine cells of the intermediate pituitary when they are cultured together in a defined culture medium. These synapses share many morphological and functional properties of those formed in situ, and this model has allowed us to reveal the dependence of spontaneously occurring IPSCs on extracellular $\mathrm{Ca}^{2+}$ concentration.

\section{Interactions between hypothalamic neurons and melanotrophs in coculture: advantages of the model}

One major advantage of our coculture system is that it is easy to distinguish between neurons and melanotrophs on a simple morphological criterion. The neurons appeared as phase-dark cells and rapidly extended neurites with time in culture. A large majority of these neurons $(>80 \%)$ were positively stained with an antibody against GAD and therefore were identified as GABAergic neurons. Melanotrophs, in contrast, were phase-bright, had a rounded appearance during the whole culture period (up to 2 weeks), and were intensely labeled with an antibody against $\alpha$-MSH. We found that GABAergic neurons and melanotrophs established contacts that displayed morphological characteristics of synapses: (1) concentration of synapsin I immunoreactivity in punctae at the level of neurites in apposition with melanotrophs; (2) clustering of electron-lucent vesicles in presynaptic axon terminals; and (3) symmetrical, moderate membrane thickening as described in situ for hypothalamo-hypophyseal synapses by Baumgarten et al. (1972). These aspects of synapse maturation were similar to those described for cultures of striatal (Weiss et al., 1986) and hippocampal (Fletcher et al., 1991) neurons.

The functionality of these contacts was demonstrated with the whole-cell recording configuration of the patch-clamp technique. Both spontaneous and evoked synaptic currents were blocked reversibly by the selective $\mathrm{GABA}_{\mathrm{A}}$ receptor antagonists bicuculline and SR95531, and the totality of synaptic activity was blocked

Table 1. Comparison of mean amplitudes and frequencies of s-IPSCs at various external calcium concentrations and effect of TTX

\begin{tabular}{|c|c|c|c|c|}
\hline & $5 \mathrm{mM} \mathrm{Ca}$ & $2.5 \mathrm{mM} \mathrm{Ca}$ & $0.3 \mathrm{~mm} \mathrm{Ca}$ & TTX $1 \mu \mathrm{M}, 5 \mathrm{~mm} \mathrm{Ca}$ \\
\hline Mean frequency & $0.31 \pm 0.24 \mathrm{~Hz}$ & $0.37 \pm 0.23 \mathrm{~Hz}$ & $0.08 \pm 0.02 \mathrm{~Hz}^{*}$ & $0.28 \pm 0.07 \mathrm{~Hz}$ \\
\hline Mean amplitude & $42.6 \pm 22.6 \mathrm{pA}$ & $36.4 \pm 6.8 \mathrm{pA}$ & $11.9 \pm 1.9 \mathrm{pA}^{* *}$ & $36.2 \pm 11.2 \mathrm{pA}$ \\
\hline Number of cells & $n=20$ & $n=8$ & $n=6$ & $n=5$ \\
\hline
\end{tabular}

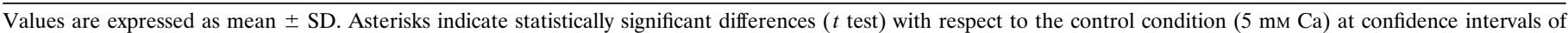
$0.03\left({ }^{*}\right)$ and $0.003\left({ }^{* *}\right)$. Values without asterisks are not significantly different from control at $p<0.05$. 
systematically by these antagonists over the culture period examined (6-14 d), suggesting that all synapses formed were GABAergic. However, it cannot be excluded that other types of synaptic contacts develop at later stages $(>14 \mathrm{~d})$ in culture (Swandulla and Misgeld, 1990).

The IPSCs recorded in our preparation share many features of GABAergic IPSCs recorded in NIL preparations (Scheggenburger and Konnerth, 1992; Borst et al., 1994) or at central synapses (Edwards et al., 1990; Kraszewski and Grantyn, 1992). These properties include fast rise times and exponential decay phases, the latter displaying clear voltage dependence, i.e., becoming slower with membrane depolarization.

It must be emphasized that the neuroendocrine synapses formed in our coculture system offer a series of advantages over neuroneuronal synapses for the electrophysiological study of synaptic transmission. These advantages can be summarized as follows. (1) The pre- and postsynaptic elements are easily identified and can be unambiguously distinguished based on simple morphological criteria. (2) The postsynaptic cell, because of its small size and absence of neurite-like processes, allows the recording of synaptic currents under good space-clamp conditions. (3) The synaptic currents, because they arise close to site of recording, are minimally distorted or attenuated by the cable properties of the cell. (4) It is possible to study synaptic transmission between pairs of cells, i.e., in a situation in which the number of synaptic boutons is small. To determine the number of synaptic boutons on an isolated melanotroph, we have started to use confocal microscopy on cocultures stained for synapsin I. Our preliminary results indicate that a neurite establishes five boutons or fewer per melanotroph (C. Egles, S. Schimchowitsch, and J. L. Vonesch, unpublished observations).

Thus, our coculture system possesses many of the criteria of an ideal preparation for the study of synaptic transmission compared with neuroneuronal synapses (for a review of the critical points, see Redman, 1990; Bekkers, 1994; Mody et al., 1994; Edwards, 1995).

\section{Kinetic properties of IPSCs}

In our preparation, the large majority of IPSCs displayed monoexponential deactivation phases, whereas the GABAergic IPSCs recorded in rat or bullfrog NIL preparations exhibit biexponential decay kinetics (Scheggenburger and Konnerth, 1992; Borst et al., 1994). This apparent discrepancy may be explained by the fact that in our study we have analyzed individual IPSCs, whereas in the studies mentioned above, kinetic analyses were performed on averaged traces of s-IPSCs and ee-IPSCs that are likely to contain a mixture of mono- and biexponentially decaying synaptic currents. In line with this, we found that averaged ee-IPSCs decayed with biexponential kinetics.

The relatively slow deactivation phase of GABAergic IPSCs in melanotrophs probably also is related to the subunit composition of the receptors. Indeed, rat melanotrophs, in contrast to many neurons, do not express the $\alpha 1$ subunit, and the expression pattern of different $\mathrm{GABA}_{\mathrm{A}}$ receptor subunits can be summarized as follows: $\alpha 2>\alpha 3 ; \beta 3>\beta 1>\beta 2 ; \gamma 1=\gamma 2$ short (Berman et al., 1994). From recombinant receptor studies, it seems that $\mathrm{GABA}_{\mathrm{A}}$ receptors containing $\alpha 3$ subunits have a lower affinity for GABA as well as slower activation, deactivation, and desensitization kinetics than receptors containing $\alpha 1$ subunits (Verdoorn, 1994; Gingrich et al., 1995; Sieghart, 1995). These features, in turn, may have important consequences on the properties of synaptic
GABAergic IPSCs (Gingrich et al., 1995; Jones and Westbrook, 1995, 1996).

\section{Quantal properties of GABAergic transmission and calcium dependence of miniature IPSCs}

Amplitude histograms of s-IPSCs in standard extracellular medium containing $5 \mathrm{mM} \mathrm{Ca}^{2+}$ did not show equally spaced peaks. This does not mean, however, that the GABAergic transmission in our system has no quantal properties (Edwards, 1995; Isaacson and Walmsley, 1995). Moreover, because TTX (1 $\mu \mathrm{M})$ did not affect significantly the s-IPSC amplitude distribution, we concluded that most s-IPSCs represented m-IPSCs.

Yet, by lowering the external $\mathrm{Ca}^{2+}$ concentration to $0.3 \mathrm{~mm}$, it was possible to isolate a single peak in the amplitude histogram at $10 \mathrm{pA}$, suggesting that the amplitude of the m-IPSCs was $10 \mathrm{pA}$, which corresponds to a synaptic conductance of $172 \mathrm{pS}$. If one assumes that the mean conductance of a single $\mathrm{GABA}_{\mathrm{A}}$ receptor channel in a melanotroph is $20 \mathrm{pS}$ (Schneggenburger and Konnerth, 1992; Borst et al., 1994), our results suggest that a quantum of GABA activates eight to nine channels. This is compatible with results obtained at other central GABAergic synapses (Edwards et al., 1990; De Koninck and Mody, 1994; Mody et al., 1994; Edwards, 1995).

Another important finding was that reducing extracellular calcium concentration to $0.3 \mathrm{~mm}$ also dramatically decreased the frequency of s-IPSCs, indicating that like the amplitude distribution of s-IPSCs, their frequency of occurrence was strongly dependent on the external $\mathrm{Ca}^{2+}$ concentration. The simplest explanation for this observation could be that a single bouton may contain several release sites interacting in a cooperative manner (Bekkers et al., 1990; Korn et al., 1993), probably as a function of the intracellular free-calcium concentration. As pointed out in the review by Edwards (1995), if several release sites coexist within a single bouton, one would predict that a change in the release probability of the neurotransmitter would change both the frequency and the amplitude distribution of the miniature IPSCs. This was effectively the case in our preparation after reduction of the extracellular calcium concentration.

An additional argument in favor of the presence of several release sites within a single bouton comes from the comparison of the amplitude distribution of s-IPSCs versus ee-IPSCs, knowing that a single afferent fiber establishes five or fewer synaptic boutons with the postsynaptic melanotroph. Indeed, the largest eeIPSCs recorded in our system had an amplitude of $\sim 1 \mathrm{nA}$. Such a current would arise from the synchronized activity of 100 individual release sites, if one assumes that the activity of a single site gives rise to an m-IPSC of $10 \mathrm{pA}$. This suggests, in turn, that each of the five boutons would host 20 release sites, a situation that is not impossible from a morphological point of view, because the average diameter of a bouton is $\sim 1.5 \mu \mathrm{m}$ in our preparation. Following the estimations presented by Edwards (1995), a postsynaptic cluster of 20 receptor channels would occupy a circle having a diameter of $40 \mathrm{~nm}$. In our system, a single bouton covers a surface of postsynaptic membrane sufficient to include $20 \mathrm{such}$ receptor clusters.

In conclusion, we have developed a model of coculture between rat hypothalamic neurons and rat melanotrophs and shown that functional GABAergic synapses are formed. This model has allowed us to reveal a clear dependence of s-IPSCs on external calcium concentration, and our experiments provide strong support for the coexistence of multiple release sites within a single synaptic bouton. We think that this model will be useful to study, 
under optimal conditions, different aspects of the synaptogenesis between a central neuron and its target as well as the cellular mechanisms underlying central synaptic transmission and its modulation.

\section{REFERENCES}

Baumgarten AG, Björklund A, Holstein AF, Nobin A (1972) Organization and ultrastructural identification of catecholamine nerve terminals in the neural lobe and pars intermedia of the rat pituitary. Z Zellforsch Mikrosk Anat 126:483-517.

Bekkers JM (1994) Quantal analysis of synaptic transmission in the central nervous system. Curr Opin Neurobiol 4:360-365.

Bekkers JM, Richerson GB, Stevens CF (1990) Origin of variability in quantal size in cultured hippocampal neurons and hippocampal slices. Proc Natl Acad Sci USA 87:5359-5362.

Berman JA, Roberts JL, Pritchett DB (1994) Molecular and pharmacological characterization of $\mathrm{GABA}_{\mathrm{A}}$ receptors in the rat pituitary. $\mathrm{J}$ Neurochem 63:1948-1954.

Björklund A, Falck B, Hromek F, Owan C, West KA (1973) Identification and terminal distribution of the tuberohypophyseal monoamine fibre systems in the rat by means of a stereotaxic and microfluorimetric technique. Brain Res 17:1-23.

Borst JGG, Lodder JC, Kits KS (1994) Large amplitude variability of GABAergic IPSCs in melanotrophs from Xenopus laevis: evidence that quantal size differs between synapses. J Neurophysiol 71:639-655.

Bottenstein JE, Sato GE (1979) Growth of a rat neuroblastoma cell line in serum-free supplemented medium. Proc Natl Acad Sci USA 76:514-519.

Bower A, Hadley ME (1972) Ionic requirements for melanophorestimulating hormone $(\mathrm{MSH})$ release. Gen Comp Endocrinol 19:147-158.

De Camilli P, Cameron R, Greengard P (1983) Synapsin I (protein I), a nerve terminal-specific phosphoprotein. I. Its general distribution in synapses of central nervous system in frozen and plastic sections. J Cell Biol 96:1337-1354.

De Koninck Y, Mody I (1994) Noise analysis of miniature IPSCs in adult rat brain slices: properties and modulation of synaptic $\mathrm{GABA}_{\mathrm{A}}$ receptor channels. J Neurophysiol 71:1318-1335.

Demeneix BA, Taleb O, Loeffler JP, Feltz P (1986) GABA-A and GABA-B receptors on porcine pars intermedia cells in primary culture: functional role in modulating peptide release. Neuroscience 17:1275-1285.

Douglas WW, Taraskevitch PS (1978) Action potentials in gland cells of rat pituitary pars intermedia: inhibition by dopamine, an inhibitor of MSH secretion. J Physiol (Lond) 285:171-184.

Douglas WW, Taraskevitch PS (1982) Slowing effects of dopamine and calcium channel blockers on frequency of sodium spikes in rat pars intermedia cells. J Physiol (Lond) 326:201-211.

Edwards F (1995) Anatomy and electrophysiology of fast central synapses lead to a structural model for long-term potentiation. Physiol Rev 75:759-787.

Edwards F, Konnerth A, Sakmann B (1990) Quantal analysis of inhibitory synaptic transmission in the dentate gyrus of rat hippocampal slices: a patch-clamp study. J Physiol (Lond) 430:213-249.

Fenwick EM, Marty A, Neher E (1982) A patch-clamp study of bovine chromaffin cells and of their sensitivity to acetylcholine. J Physiol (Lond) 331:577-597.

Fletcher TL, Cameron P, De Camilli P, Banker G (1991) The distribution of synapsin I and synaptophysin in hippocampal neurons developing in culture. J Neurosci 11:1617-1626.

Gingrich KJ, Roberts WA, Kaas RS (1995) Dependence of the GABA receptor-gating kinetics on the $\alpha$-subunit isoform: implication for structure-function relations and synaptic transmission. J Physiol (Lond) 489:529-543.

Hamann M, Desarmenien M, Desaulles E, Bader MF, Feltz P (1988) Quantitative evaluation of the properties of a pyridazinyl GABA-A derivative (SR95531) as a GABA-A antagonist. An electrophysiological approach. Brain Res 442:287-296.

Hamill OP, Marty A, Neher E, Sakmann B, Sigworth FJ (1981) Improved patch-clamp technique for high resolution current recording from cell and cell-free membrane patches. Pflügers Arch 391:85-100.

Isaacson JS, Walmsley B (1995) Counting quanta: direct measurements of transmitter release at a central synapse. Neuron 15:875-884.
Jones MV, Westbrook GL (1995) Desensitized states prolong GABA channel responses to brief agonist pulses. Neuron 15:181-191.

Jones MV, Westbrook GL (1996) The impact of receptor desensitization on fast synaptic transmission. Trends Neurosci 19:96-101.

Kaneko A, Tashibana M (1986) Blocking effect of calcium and related ions on the gamma-aminobutyric acid induced in turtle retina cones. J Physiol (Lond) 373:463-469.

Korn H, Bausela F, Charpier S, Faber DS (1993) Synaptic noise and multiquantal release at dendritic synapses. J Neurophysiol 70:1249-1254.

Kraszewski K, Grantyn R (1992) Unitary, quantal, and miniature GABA-activated synaptic chloride currents in cultured neurons from the rat superior colliculus. Neuroscience 47:555-570.

Ma JY, Narahashi T (1993) Enhancement of gamma-aminobutyric acidactivated chloride channel currents by lanthanides in rat dorsal root ganglion neurons. J Neurosci 11:4872-4879.

MacDonald RL, Olsen RW (1994) GABA-A receptor channels. Annu Rev Neurosci 17:569-602.

MacVicar BA, Pittman QJ (1986) Novel synaptic responses mediated by dopamine and gamma-aminobutyric acid in neuroendocrine cells of the intermediate pituitary. Neurosci Lett 64:35-40.

Mody I, De Koninck Y, Otis TS, Soltesz I (1994) Bridging the cleft at GABA synapses in the brain. Trends Neurosci 17:517-525.

Oertel WH, Mugnaini E, Tappaz ML, Weise VK, Dahl AL, Schemchel DE, Kopin IJ (1982) Central GABAergic innervation of neurointermediate lobe. Biochemical and immunocytochemical study in the rat. Proc Natl Acad Sci USA 79:675-679.

Redman S (1990) Quantal analysis of synaptic potentials in neurons of the central nervous system. Physiol Rev 70:165-198.

Schneggenburger R, Konnerth A (1992) GABA-mediated synaptic transmission in neuroendocrine cells: a patch-clamp study in a pituitary slice preparation. Pflügers Arch 421:364-373.

Sieghart WW (1995) Structure and pharmacology of $\gamma$-aminobutyric acid-A receptor subtypes. Pharmacol Rev 47:181-234.

Swandulla D, Misgeld U (1990) Development and properties of synaptic mechanisms in a network of rat hypothalamic neurons grown in culture. J Neurophysiol 64:715-726.

Taraskevitch PS, Douglas WW (1982) GABA directly affects electrophysiological properties on pituitary pars intermedia cells. Nature 276:733-734.

Taraskevitch PS, Douglas WW (1985) Pharmacological and ionic features of GABA receptors influencing electrical properties of melanotrophs isolated from the rat pars intermedia. Neuroscience 14:301-309.

Tilders FJH, Bekenbosch F, Smelik PG (1985) Control of secretion of peptides related to adrenocorticotropin, melanocyte-stimulating hormone, and endorphin. Front Horm Res 14:161-196.

Tomiko SA, Taraskevitch PS, Douglas WW (1981) Potassium-induced secretion of melanocyte-stimulating hormone from isolated pars intermedia cells signals participation of voltage-dependent calcium channels in stimulus secretion coupling. Neuroscience 6:2257-2269.

Tomiko SA, Taraskevitch PS, Douglas WW (1983) GABA acts directly on cells of pituitary pars intermedia to alter hormone output. Nature 301:706-707.

Valentijn JA, Louiset E, Vaudry V, Cazin L (1991) Dopamine-induced inhibition of action potentials in cultured frog pituitary melanotrophs is mediated through activation of potassium channels and inhibition of calcium and sodium channels. Neuroscience 42:29-39.

Verdoorn TA (1994) Formation of heteromeric $\gamma$-aminobutyric type A receptors containing two different $\alpha$ subunits. Mol Pharmacol 45:475-480.

Vincent SR, Hökfelt T, Wu JY (1982) GABA neuron systems in hypothalamus and pituitary gland. Immunohistochemical demonstration using antibodies against glutamate decarboxylase. Neuroendocrinology 34:117-125.

Vuillez P, Carbajo-Perez S, Stoeckel ME (1987) Colocalisation of GABA and tyrosine hydroxylase immunoreactivities in the axon innervating the neurointermediate lobe of the rat pituitary: an ultrastructural immunogold study. Neurosci Lett 79:53-58.

Weiss S, Pin JP, Sebben M, Kemp DE, Sladeczek F, Gabrion J, Bockaert J (1986) Synaptogenesis of cultured striatal neurons in serum-free medium: a morphological and biochemical study. Proc Natl Acad Sci USA 83:2238-2242.

Williams PJ, MacVicar BA, Pittman QJ (1989) A dopaminergic IPSP mediated by an increased $\mathrm{K}^{+}$conductance. Neuroscience 31:673-681.

Williams PJ, MacVicar BA, Pittman QJ (1990) Synaptic modulation by dopamine of calcium currents in rat pars intermedia cells. J Neurosci 10:757-763. 